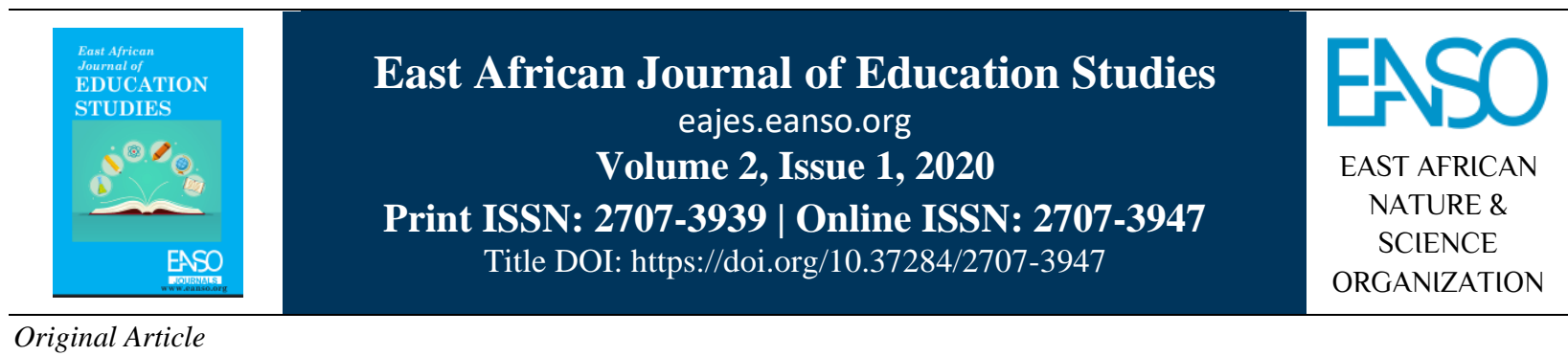

\title{
Academic Performance in Islamic University Primary School: Causes of Poor Performance and Anticipated Remedy. A Study Commissioned by the Executive Board of Islamic University in Uganda
}

\author{
Dr. Amina Hassan ${ }^{*}$, Dr. Ssali Muhammadi Bisaso ${ }^{1}$, Isa Ssekanyo ${ }^{1}$ \& Rehema Kantono ${ }^{1}$ \\ ${ }^{1}$ Islamic University in Uganda, P. O. Box 2555, Mbale, Uganda. \\ *Author for Correspondence Email: hamina.hassan229@gmail.com or a.hassan@iuiu.ac.ug \\ * ORCID: https://orcid.org/0000-0002-1802-1075.
}

Article DOI: https://doi.org/10.37284/eajes.2.1.210

Date Published: ABSTRACT

11 September 2020 The study explored the causes of poor academic performance and anticipated remedy in Islamic university primary school. The study was qualitative in nature

Keywords: and case study design was used. Purposive sampling technique was used to

Academic Performance,

Causes,

Poor Performance,

Remedy,

Primary School. select 28 respondents who were interviewed. Data was collected through semistructured interviews, documentary analysis and observation. The thematic analysis method was used to analyse data. The findings revealed that the causes of poor academic performance included, absenteeism, poor feeding, language problem, negative teachers' attitude, inadequate support from administration, and poor school environment. The researchers developed a tool to help improve the academic performance in Islamic university primary school. The tool explains that the school should provide professional administration, teacher motivation, in-service training, learners' guidance and counselling, improve learners' communication skills and provide a conducive school environment to improve the academic performance of the pupils.

\section{APA CITATION}

Hassan, A., Bisaso, S., Ssekanyo, I., \& Kantono, R. (2020). Academic Performance in Islamic University Primary School: Causes of Poor Performance and Anticipated Remedy. A Study Commissioned by the Executive Board of Islamic University in Uganda. East African Journal of Education Studies, 2(1), 105-114. https://doi.org/10.37284/eajes.2.1.210.

\section{CHICAGO CITATION}

Hassan, Amina, Ssali Bisaso, Isa Ssekanyo, and Rehema Kantono. 2020. "Academic Performance in Islamic University Primary School: Causes of Poor Performance and Anticipated Remedy. A Study Commissioned by the Executive Board of Islamic University in Uganda". East African Journal of Education Studies 2 (1), 105-114. https://doi.org/10.37284/eajes.2.1.210. 


\section{HARVARD CITATION}

Hassan, A., Bisaso, S., Ssekanyo, I. and Kantono, R. (2020) "Academic Performance in Islamic University Primary School: Causes of Poor Performance and Anticipated Remedy. A Study Commissioned by the Executive Board of Islamic University in Uganda", East African Journal of Education Studies, 2(1), pp. 105-114. doi: 10.37284/eajes.2.1.210.

\section{IEEE CITATION}

A. Hassan, S. Bisaso, I. Ssekanyo, and R. Kantono, "Academic Performance in Islamic University Primary School: Causes of Poor Performance and Anticipated Remedy. A Study Commissioned by the Executive Board of Islamic University in Uganda", EAJES, vol. 2, no. 1, pp. 105-114, Sep. 2020.

\section{MLA CITATION}

Hassan, Amina, Ssali Bisaso, Isa Ssekanyo, and Rehema Kantono. "Academic Performance in Islamic University Primary School: Causes of Poor Performance and Anticipated Remedy. A Study Commissioned by the Executive Board of Islamic University in Uganda". East African Journal of Education Studies, Vol. 2, no. 1, September 2020, pp. 105-114, doi:10.37284/eajes.2.1.210.

\section{INTRODUCTION}

This study was commissioned by the executive board of Islamic university in Uganda (IUIU) after the Dean, Faculty of Education presented a report about Islamic University primary school (IUPS). The Executive Board was concerned about the appalling results in the report for the last five years (2015-2019) whereby there was no single first grade, most of the students scored third grade, and above all, some students registered total failure, they could not be graded. It is upon this background that the study was commissioned.

Dagnew (2018) defined academic achievement as the performance of the students in the subject they study in school. Learners' academic performance is a key feature in education. Dagnew (2018) notes that it determines the students' status in class, and helps in choosing students for various courses. Fehintoll (2009) observed good academic performance gives parents and students feelings of satisfaction and joy. According to Tobishima (2018), it determines later educational attainment. Regier (2011) observed that academic success has numerous values like leads to employment opportunities, higher salaries, less likely to engage in criminal activity, more active as citizens, and many more.

Despite the numerous values attached to good academic achievement, Islamic University primary school exhibit less impressive performance to the expectation of the stakeholders. Within the last five years, from 2015-2019, the school did not register any first grade, most of the learners score third grade, and worst of all some registered total failure (source primary leaving examinations results
(PLE), 2015-2019). The headteacher reiterates "learners try hard but the school has challenges which do not enable learners to perform well." A former pupil observed "the PLE results are less impressive compared to the expectations of the school" (St 2).

The findings of different studies revealed that learners' poor academic performance is caused by different factors such as absenteeism, teacher factor, parental factor, school climate, academic self-concept, parenting style, learners' attitude, and many more (Hidayat et al., 2012; Dagnew, 2018; Fehintolla, 2009; Kaigama, Giroma, \& Also, 2019; Adelabu, 2007; Voight \& Hanson, 2017). However, these studies did not focus on the causes of poor academic performance in Islamic University primary school in Mbale District in Uganda. One wonders whether such factors were similar to those causing poor academic performance in Islamic university primary school.

The purpose of this study is to understand the academic performance of learners at the Islamic university primary school in Mbale in Uganda. Specifically, the study sought to:

i) Find out the causes of poor academic performance at Islamic University primary school.

ii) To suggest a remedy to improve academic performance in Islamic University primary school.

Islamic university primary school falls under the universal primary school (UPE). The school was founded by the Islamic university in Uganda to 
offer education services to the community around it. Islamic university primary school serves various communities which include; Nkoma, Busajjabwankuba, Nakaloke, Buyonjo, and many more. Islamic university primary school is found in the Eastern region of Uganda which is an upcountry school. It is located along Mable Soroti road. Islamic university primary school has slightly more than 400 children and 14 teachers.

\section{LITERATURE REVIEW}

Several related studies have been carried out on pupils' academic performance in primary schools. Some of these studies include Kariuki, Njoka, and Mbugua (2019) who evaluated teacher preparedness on pupils' performance in mathematics in lower primary schools in the Aberdare region of Kenya. They focused on preparing a scheme of work and lesson a plan in teaching mathematics. The study used a descriptive survey design and constructivism theory. The respondents included teachers and students. The study revealed that there was a significant difference between teachers' preparedness and performance in mathematics. Biao (2018) studied supplying basic education and learning to subSaharan Africa in the twenty-first century in Botswana. Gyansah, Soku, and Esilfie (2015) examined child delinquency and pupils' academic performance in Fmesua Municipal Assembly primary school in the Ejisu Juaben Municipality in Ghana. Specifically, the study looked at the causes of child delinquency, the influence of child delinquency on education, and remedy to this situation. The study was qualitative, purposive sampling was used to select 40 learners and 9 teachers. The methods used to collect data were the interview method and documentary analysis. Findings revealed that financial, peer influence, and poor performance were among the causes of delinquency. They recommended guidance and counselling, proper parenting, and small class size as ways of remedy. Fitzpatrick (2014) was concerned about bridging the gap between advantaged and disadvantaged children in South Africa. This study used a Meta-analysis approach.

Uganda in particular has some studies described below. Matovu (2019) analysed quality assurance key performance indicators in research in Ugandan
Universities. The objectives included understanding the roles of quality assurance key performance indicators, perception of staff on these key performance indicators, and examining the quality assurance key performance indicators variables. The study was quantitative in nature. Whereas Matovu (2019) focused on Islamic University in Uganda, this study focused on Islamic university primary school in Uganda. Nabbuye (2018) examined the educational policies in Uganda with special attention to those that support the use of gender sensitivity in the curriculum and classroom. Ndungo and Biira (2018) examined the teachers' quality factors that are thought to affect pupils' achievement in mathematics in primary six. The study was quantitative in nature; both teachers and students were respondents. Seventy respondents were selected using a simple random sampling technique. The study found that teacher commitment is highly significant to pupils' performance in mathematics. Namara \& Kasaija (2016) examined the effects of collective action of teachers on their welfare. The study was qualitative in nature. The researchers interviewed officials from the National teacher's union, primary teachers, and officials from the Ministry of Education and Sports. The study found that the collective efforts of teachers had minimal effects on teachers' welfare. Okurut (2015) examined the effect of automatic promotion on pupils' learning achievement in Uganda's primary education. The study was quantitative in nature. It used a difference-in-differences analysis technique. The study revealed that automatic promotion resulted in an increased outcome in the English language and mathematics. Whereas the above studies were on primary schools in Africa and Uganda in particular, the current study focused on causes of poor academic performance in peri-urban primary schools under UPE a case study of the Islamic primary school in Uganda.

\section{METHODOLOGY}

\section{Research Design}

The study was qualitative and used a Case study approach. We used a qualitative approach to develop a thick description of the causes of poor academic performance of learners and anticipated remedies in Islamic university primary school. The 
qualitative approach helps to gain much insight into the phenomenon. The population of the study comprised of three (3) school administrators, 14 teachers in the school, 5 parent representatives in the school management committee, and primary leaving examinations (PLE) candidates for 2018 (41) and 2019 (40). 2018 and 2019 were selected because their performance was worse compared to 2017 and 2016. The Total population in the study is 103. The sample size comprised of 3 school administrators, teachers of upper primary (4), 5 parent representatives in the school management committee, 8 best-performing students and these scored second grade and 8 students who scored 4 th grade. This was intended to neutralize the bias in responses from good and poor performing students. According to Wiesma (1995) in purposive sampling, subjects are selected because of the data they can provide relevant to the research question. Patton (1990) argues that it is important to select information-rich cases for study in depth. The total sample in the study was 28 informants. Qualitative studies do not require a large sample, the researchers stopped sampling after data saturation. Wiesma (1995) argued that the sample size in qualitative research is typically small. But the exact number is not specified.

The study used the following techniques of data collection; interviews, documentary review, and observation. Documents reviewed included; reports of various meetings, duty weekly reports, SMC meeting reports, teacher's supervision tool, weekly attendance report, and PLE results. To ensure the credibility of the study, the researchers designed the instrument for data collection. A pilot study was carried out on two informants to ensure that the information required was enlisted. Adjustments were made where necessary. Triangulation of data was done through multiple informants including parents, administrators, teachers, and pupils. Multiple researchers were also another form of triangulation and member checking where preliminary findings were presented to some of the informants to ensure that there is no contradiction with what they said.

\section{Data Analysis}

Adopting Braun and Clarke's (2006) thematic model, qualitative data was analysed by familiarizing them with data by reading the text several times. The researchers coded the main ideas identified. The researchers then grouped the codes into sub-themes. Later the researchers grouped the sub-themes to form various themes of the study. Findings were presented following the research objectives and the themes generated.

\section{FINDINGS}

\section{Causes of poor performance in Islamic university primary school}

The findings are grouped under 7 themes; absenteeism, poor feeding, language problem, poor school environment, inadequate support from parents, teachers' attitude, and limited support from administration.

\section{Absenteeism}

This study revealed that absenteeism is one of the causes of poor academic performance in IUPS. From the documentary analysis, the study revealed that there is poor attendance of both learners and teachers in the first weeks of the term. This affects syllabus coverage and hence affecting their performance. During the follow-up weeks, there is irregular attendance among the pupils with large variances for the upper classes (P6 \& P7). It was noted that the absenteeism from school is remarkable. (Weekly attendance reports, 2019). (Beginning of term III minutes, 2019), (SMC Meeting, 2018). It was also noted that Teachers dodge classes /lessons while seating in the staffroom (STIR, Meeting)

The study further revealed that learners always escape from school and dodge lessons and the reasons include; "doing chores at home" (St 2), lack of school fence "you can't blame them when there is no fence" (P 3). A parent reiterates "sometimes teachers miss, sometimes learners miss lessons" (P 1 ). Some students performed poorly because they arrived late at school hence miss some lessons. One student reported that he "... performed poorly due to late arrival at school" (St 2).

This study is in agreement with Hidayat et al. (2012) who established that there is a negative association between students academic performance and hours of absence in their courses. 
The study also indicated that students with poor performance reported more absences than those students with high performance.

\section{Poor Feeding}

The study found that pupils performed poorly because of poor feeding at the Islamic university primary school, some even go on an empty stomach because the parents cannot afford to pay for the pupils' lunch. Such pupils cannot concentrate to learn hence poor results. Some leave the school to go and look for lunch and they fail to come back for afternoon classes. One student from the school said, "feeding program is absent for those who do not pay" (St 2). A teacher from the school also said, "imagine a teacher having breakfast and lunch but still breakdown, what about the children who study on empty stomachs?" (T1). This is supported by results from an analysis of the School management committee report which revealed that there are poor fees payment and lack of meals among the majority of pupils. (Minutes of SMC meeting, 2018).

\section{Language Problem}

The study revealed that the pupils are not faring well in the English language. They cannot read and interpret work, can't write spelling correctly and pupils cannot express themselves in the English language fluently. One former student revealed that the standard of primary leaving examination English was high. Meaning that they could not understand the questions clearly hence could not answer them as expected. The document review revealed that learners could not read and interpret the work in the lower classes (beginning of term III staff meeting minutes, 2019)

\section{Poor School Environment}

The Islamic university's primary school environment is wanting, it is a waterlogged area and classified as hard to reach. During the rainy season, the school is not accessible hence so many learners and teachers miss classes. This affects syllabus coverage and eventually impacts on the learners' academic performance. A teacher reiterates "in fact, some teachers are posted but they seek immediate transfers upon realizing the environment" (T 1). "Water is much when it rains...how he will cross the mud..." (Tr). The document review revealed that student and teacher attendance was affected by the rainy season and flooding of the school compound (teacher on duty weekly report, 2019), (SMC Meeting, 2019). The access road to the school is also appalling. It becomes impassable during the rainy season leading many children and staff to miss classes. The headteacher said "... the access road is terrible, when it rains it is like a garden. You need gumboots..." The documents revealed that concern has been raised on the poor state of the access road to the school. (Teacher on duty weekly report, 2019) (Minutes of SMC, 2016, 2018). Observation results also revealed that during the rainy season the place is muddy and the access road to the school is impassable.

Furthermore, the lack of a school fence is another concern. This allows the students to move in and out anytime "one student said, "... the school has no fence". The school treasurer said, "... the school does not have a fence...". There is insecurity in the school due to the lack of a fence and security guard. Several items have been stolen like solar panels, doors, water pipes, a water tank, etc. People also move freely through the school compound hence destructing the attention of learners in classes. This finding is contrary to Cohen, McCabe, Micheli \& Pickeral (2009) who observed that school climate; the social, emotional, and physical characteristics of a school are gaining more attention as a lever to improve student academic performance.

\section{Inadequate Support from Parents}

The study revealed that the Islamic university's primary school parents have failed to meet their obligations towards their children to support their academic performance. Parents have failed to pay the urban charges, pay minimal visits to the school, attend meetings, and they have a culture of taking the best performing children to other schools. The study revealed that parents fail to pay the official municipal council urban charge of 15,000 UGX and feeding fees which would support improving the performance of learners. This is supported by a teacher who said, "failure to meet the official municipal council urban charge of 15,000 leading to missing of tests and lessons" (t 4). Another interviewee said "...parents are weak they left everything to the school. They don't mind about 
their children" (T). It was noted from the documents that concern was raised about poor fees payment and lack of meals among the majority of pupils (minutes of SMC, 2018). Parents rarely visit the school to learn more about their children's performance, discipline, needs, and many more. Failure to follow up on their children affects their performance. A parent said, "am always here but I take long to see parents coming to the school" (P1). "They don't even come to check on their children's performance in class..." (HM).

The study further revealed that parent-teacher meetings (PTA) are irregular where various issues can be discussed including learners' performance. A parent said, "last year there was none to the best of my knowledge" meaning that there was no parentteacher meeting held in the previous year. Another interviewee said, "lack of parent's meetings these days" (Sc N). This was also supported by a documentary review which revealed that parents neither attend school meetings nor provide school requirements (SMC meeting, 2018). This is supported through observation in 2019 when parents were invited for a meeting. A few turned up and the headteacher had to send the pupils back home to come with their parents.

Parents also have a culture of taking away the best performing pupils from Islamic university primary schools. This is supported by one interviewee who said," ... some parents think their children are wasted at Islamic university primary school that is why term two returnees are normally few" $(\operatorname{Tr} 1)$. Another interviewee said, "... we have high transfer especially the clever ones from number 1 to $10 \ldots$ the good ones are taken to other schools" (HM). This is supported by the documentary analysis of various pupils in the school results reports. Consideration was taken on a class of pupils as they were promoted from P5 up to P7. It was observed that out of 47 pupils in P5 in term III 2016, the school only retained 14 in P7 by 2018 term II. The above observation suggests a high turnover rate as pupils either drop out or joins other schools in the due course. Further still, the performance of the focus group declines as they progress to the upper classes.

(Dagnew, 2018) found that, parenting style, academic self-concept, and academic motivation had a significant positive relationship with academic performance.

\section{Negative Teachers' Attitude}

The study also found that there was a negative attitude of teachers towards the Islamic university primary school. Some teachers even seek a transfer as soon as they are posted to the school. This finding is supported by one interviewee who said, "... some of our teachers have a fixed mindset. They fear to teach in the Islamic school... we lack teachers who have changed minds..." (HM). This finding is resonate to Strong (2007) who identified many common elements of effective teaching. Among them is teachers' attitude, without the proper attitude, effective teaching cannot take place.

\section{Limited Support from School Administration}

The study also revealed that limited support from the administration has contributed to the poor performance. Both the school administration and the foundation body has been accused of failing to motivate the teachers adequately. A teacher said, "some expect big from the administration" "what has the management done - in this case, IUIU" (T $1)$.

It has also been found that school administrators do not call for regular meetings like SMC, staff meetings, and AGM. It is in such forums that various issues can be discussed including learners' performance. The study revealed that when district officials come they do not interact with the learners. They only move around and interact with the school administrators. "...when they come, they only move around and talk to the headteacher" (St 2). It was also found that school administrators do not administer frequent tests for P7 class which would have improved their performance. A student said, "we did only three tests per term in primary seven while other schools do 2 per week" term (St 2).

\section{Remedies to Improve Academic Performance at Islamic University Primary School}

To address the challenge of absenteeism, the researchers recommended some measures which include; to roll call pupils, guidance and counselling pupils, sensitizing parents to send 
pupils to school early, and punishing latecomers. We hope that such measures will stimulate the learners to be conscious of their studies and start attending seriously. These suggestions are supported by many studies that include: Nzoka (2014) recommended schools in Embu County in Kenya to put in place an operational guidance and counselling unit. Nzoka (2014) advocated that the individual schools should work out modalities of training their teachers to enable them to carry out the duties of guidance and counselling well.

To address the English language problems and grades the following measures were suggested; to organize debates every fortnight, to organize quiz at least once every week during a period of class teaching, and test for candidate class every fortnight. These measures will enable the students to practice their language, master the language, and build their confidence in expressing themselves. One respondent said "... they should have regular tests... for $\mathrm{p} 6$ and $\mathrm{p} 7$ to improve performance ...) (HT). "Like I said that for us we do a few tests and exams, more practice would help us..." St 2)

Furthermore, we recommend design-based reading whereby the teacher forms small groups of about 5 members. They are given texts to read to achieve a particular objective, for example improving vocabulary. After reading in small groups the teacher can test the whole class if the objective was achieved. (O'connor, Beach, Sanchez, Bocian \& Flynn (2015)

The research further suggested that learners should be engaged in school activities to improve their attitude towards learning. Adelabu (2007) observed that when a sense of school engagement is positive, students tend to participate more in school activities. Erdoğdu (2019) found that when the attitude towards learning is positive, individuals are more academically successful.

To address the challenge of poor feeding the school administration should call for parents meeting so that the issue is discussed extensively and the solution arrived at. The school should also build a canteen where edibles can be sold so that learners do not move out of school to buy edibles. Parents should also be sensitized to pay the feeding fees to enable their children to access food. Abosti (2013) found that feeding in schools had positive effects on school enrolment and school academic performance in elementary Ghanaian schools. He recommended that the schools should involve the community in the feeding program instead of depending on donna support to feed their children for the feeding program to be sustainable.

To improve on the environment the following suggestions can apply; to fence the school, to murram the road to the school and the school compound, to renovate the classes, and to dig trenches around the compound for water outlet. This will make the school environment appealing. Some respondents suggested; "...plant Chogyam trees and then put zigzag fence..." (T). "The structures are not so bad compared to other nearby schools, but they need some simple renovation" (P 1). "... build staff quota to accommodate the teachers..." (Tr). Abosti (2013) recommends that the government together with the school's authorities should provide a suitable learning environment, adequacy of educational infrastructure since these have been found to influence the academic performance of students.

To bring the parents on board; parent-teacher meetings should be revived to sensitize parents to meet their obligation, organise seminars for parents, visit individual parents about their child. This will create awareness and incite for the parents to be more responsible for their child. Ndyali (2013) recommends that school heads should involve community members in various school affairs to make sure they contribute positively to the achievement of students' academic performance.

To improve teachers' attitudes, the school should try its best to motivate the teachers by providing some incentives like breakfast, lunch, and transport. The administration should improve supervision and provide professional development. One respondent advised "since IUIU has many lecturers especially at faculty of education, they could come and give us help in both supervision and professional development" (T1). "...facilitation of teachers' awards... this can help in motivating the teachers to do well" (T1). Abosti (2013) recommended policies that will ensure a high quality of teaching and learning such as teacher motivation, good condition of service as well as proper supervision and 
management to improve learners' academic performance.

To improve the administration's concern, Ndyali (2013) observed a school head must provide professional leadership for the continuous improvement of the school. He or she must have a vision of what should be achieved. The proper vision has clear strategies on how to fulfil it to attain effective teaching, students' achievement in learning, spiritual, moral, cultural, mental, and physical achievement. Furthermore, the school head should coordinate properly all the required resources to get the desired outcomes. The resources include both human and nonhuman resources. Wameru and Orodho (2013) in their study advised the school principal to endeavour to provide the best school climate to entice students to complete schooling by making school free from violence, threats, intimidation, hatred, and witchhunting. They should also develop rich cocurriculum, remedial interventions for slow learners to avoid repetition, frustration, and dropout.

\section{DISCUSSION}

The study revealed that absenteeism, poor feeding, teachers' negative attitude, language problems, wanting administration, and poor environment are the factors that cause poor academic performance at IUPS. The researchers observed that these causes of poor performance could be rotating around poor administration. Allen (1981) observed that a leader of a school is paramount in determining the school climate. The leader plays a significant role in determining the smooth running of a school. In case the leader is not effective, anything can go wrong in the school for example leaner poor academic performance. The researchers believe the founding body IUIU relaxed its efforts in supporting the school since the school was taken over by the government. The founding body needs to be more involved in the management of the school. They need to put in place quality assurance indicators for the school and implore the school administration to implement such guidelines.

The school administration also needs to be a little more proactive to ensure that there is improved performance. They should know that once the performance improves, parents will gain trust in the school and bring more children to the school and also support the school financially and otherwise. Fehintolla (2009) observed that when students excel academically, it gives parents and students feelings of satisfaction and joy. Strong (2007) identified various common elements of effective teaching, which he categorized into six broad terms. Among which are; "the teacher as a person" (including caring, fairness and respect, social interactions, enthusiasm, and motivation, attitude and reflective practice), "classroom management and organization" which include planning and organization of instruction and finally "monitoring student progress and potential". For the IUPS teachers to excel, they need to consider all these aspects and put them to practice. This is where the administration needs to plan for in-service training to revive all these practices for the teachers. Nisimiyu and Amina (2013) found that in-service training improved teachers' performance in Mbale Municipality primary schools.

\section{CONCLUSION AND RECOMMENDATION}

The study revealed that absenteeism, poor feeding, teachers' negative attitude, language problems, wanting administration, and poor environment are the factors that cause poor academic performance at IUPS. The study developed a tool for improving the academic performance of Islamic university primary school that is presented below:

\section{Figure 1: Tool to improve academic performance in Islamic University Primary School}

\section{Tool for academic performance}

1. Professional leadership

2. Teachers motivation

3. In-service training

4. Parental involvement

5. Guidance \& counselling

6. Communication skills

7. School environment
Academic performance

- High academic performance 
The researchers concluded that Islamic university primary school needs to adopt the above tool in order to improve the academic performance of the school.

The researchers recommend that the founding body of the school should follow-up to ensure that the tool is implemented.

\section{REFERENCES}

Abotsi, A. K. (2013). Expectations of school feeding programme: Impact on school enrolment, attendance, and academic performance in elementary Ghanaian schools. British Journal of Education, Society \& Behavioural Science, 3(1), 76-92.

Adelabu, D.D. (2007). Time perspective and school membership as correlates to academic achievement among African American adolescents. Adolescence, 42(167), 525-538

Allen, T. H. (1981). Situational management style: A conceptual model. Doctoral dissertation, US international University. Dissertation abstracts international, 42, $2 \mathrm{~A}$.

Biao, I. (2018). Supplying basic education and learning to sub-Saharan Africa in the twentyfirst century. World journal of education, 8(2).

Braun, V., \& Clarke, V. (2006). Using thematic analysis in psychology. Qualitative Research in Psychology, 3, 77-101.

Cohen, J., McCabe, E. M., Michelli, N. M., \& Pickeral, T. (2009). School climate: Research, policy, and teacher education. Teacher College Record, 111(1), 180-213.

Dagnew, A. (2018). Relationship among parenting style, academic self-concept, academic motivation, and students academic achievement in Fasilo secondary school, Bahir Dar, Ethiopia. Research in Pedagogy, 8(2), 98110. DoI: $10.17810 / 2015.76$

Erdoğdu, M. Y. (2019). The Mediating Role of School Engagement in the Relationship between Attitude toward Learning and Academic Achievement. International Journal of Education and Literacy Studies, 7(2), 75-81.
Fehintolla, J. O. (2009). The effect of family background and environmental factors on academic achievement of secondary school students. A study of selected secondary school students in Saki West Local Government area. International journal of distance education, 4 , $51-56$

Fitzpatrick, C. (2014). Bridging the gap between advantaged and disadvantaged children. Why should we be concerned with executive functions in the South African context? Journal of childhood education, 4(1), 156-166

Hidayat, L., Vansal, S., Kim, E., Sullivan, M., \& Salbu, R. (2012). Pharmacy student absenteeism and academic performance. American Journal of Pharmaceutical Education, 76(1).

Jama, P. M. (2016). Academic guidance for undergraduate students in a South African medical school: Can we guide them all? Journal of students' affairs, 4(2), 13-24.

Kariuki, I. W., Njoka, J. N., and Mbagua, Z. K. (2019). Influence of teachers' preparedness on performance of pupils in mathematics in lower primary schools in the Aberdares region of Kenya. European journal of stem education, 4(1) 01.

Matovu, M. (2019). An analysis of quality assurance key performance indicators in research in Ugandan universities. International journal of instruction, 12(1), 1567-1584.

Nabbuye, H. (2018). Gender-sensitive pedagogy. The bridge to girls' quality education in Uganda. Ecidna global scholars program policy brief. Centre for universal education at Brookings.

Namara, B. R. \& Kasaija, J. (2016). Teachers protest movements and prospects for teachers improved welfare in Uganda. Journal of education and training studies, 4(5).

Ndungo, I and Biira, M. (2018). Teacher quality factors and pupils achievement in mathematics in primary schools of Kyondo sub county, Kasese District, Uganda. Academia journal of 
educational research, 6(7). Doi: 10.15413/ajer.2018.0117

Ndyali, S. T. (2013). The role of school head in enhancing students' academic performance in community secondary schools in Mbeya Urban. A masters' dissertation, Open University of Tanzania.

Nisimiyu, L. \& Amina, H. (2013). The impact of inservice training on teachers' performance in Mbale Municipality primary schools. Islamic University journal, 3(2), 20-29

Nzoka, T. J. (2014). School management and students' academic performance. How effective are strategies being employed by school managers in secondary schools in Embu North District, Embu County, Kenya? Intentional Journal of Humanities and social science, 4(9), 86-99.

O'Connor, E.R., Beach, D. K., Sanchez, V., Bocian, M. K. and Flynn, L. (2015). Building bridges: A design experiment to improve reading and United States. History knowledge of poor readers in $8^{\text {th }}$ grade. Experimental children, 81, 399-425

Okurut, M., J. (2015). Examining the effect of automatic promotion on students' learning achievements in Uganda's primary education. World Journal of Education, 5(5), 85-100.

Patton, M. Q. (1990). Qualitative evaluation and research methods (2 ed.). Newbury Park: Sage.

Regier, J (2011). 2011 applied science and technology scholarship. Saskatchewan school boards association.

Strong, J. H. (2007). Qualities of effective teachers $\left(2^{\text {nd }} e d.\right)$. Alexandria VA: Association for supervision and curriculum development (ASCD).

Tobishima, S. (2018). Family structure and children's academic achievement in Japan. A quantile regression approach. Educational Studies in Japan: International yearbook, 12, 107-119.
Voight, A. and Hanson, T. (2017). How are middle school climate and academic performance related across schools over time? (REL-2017212). Washington, DC:US. Department of education, institute of education science, National Centre for education evaluation and regional assistance, regional educational laboratory west.

Wameru, P., N. \& Orodho, A., J. (2013). Management practices and students' academic performance in national examinations in public secondary schools in Kiambu County. International Journal of scientific research, 15(20), 472-479.

Wiesma, W. (1995). Research methods in education. An introduction. Boston: Allyn and Bacon. 